\title{
DOMESTIC TOURIST SATISFACTION: IMPLICATIONS FOR “ONE COMMUNE ONE PRODUCT” ECO-TOURISM DEVELOPMENT IN THE MEKONG DELTA OF VIETNAM
}

\author{
Nguyen Thuy TRANG \\ Can Tho University, College of Rural Development, Department of Rural Socio-Economics, Can Tho, Vietnam, e-mail: nttrang@ctu.edu.vn \\ Vo Hong TU* \\ Can Tho University, College of Rural Development, Department of Rural Socio-Economics, Can Tho, Vietnam, e-mail: vhtu@ctu.edu.vn
}

\begin{abstract}
Citation: Trang, N.T. \& Tu V.H. (2021). DOMESTIC TOURIST SATISFACTION: IMPLICATIONS FOR “ONE COMMUNE ONE PRODUCT" ECO-TOURISM DEVELOPMENT IN THE MEKONG DELTA OF VIETNAM. GeoJournal of Tourism and Geosites, 38(4), 1042-1050. https://doi.org/10.30892/gtg.38408-742
\end{abstract}

\begin{abstract}
Eco-tourism being one of six groups of OCOP products plays a key role in the rural economic development. However, there are limited empirical evidences on the impacts of destination attributes of OCOP tourism on tourist satisfaction. Thus, the objective of this current study is to investigate the impacts of OCOP eco-tourism destination attributes on tourist satisfaction. The study conducted face-to-face interviews with 200 eco-tourists and employed exploratory factor analysis and multiple regression. The study found that the shared social and environmental responsibilities - core characteristics of OCOP tourism have the highest effect on tourist satisfaction. The study also provides some policy implications for sustainable development of OCOP eco-tourism destinations in the Mekong Delta.
\end{abstract}

Key words: destination attributes, eco-tourism, exploratory factor analysis, OCOP, tourist satisfaction

$* \quad * \quad * \quad * \quad * \quad *$

\section{INTRODUCTION}

Eco-tourism is a type of tourism that brings sustainable benefits and invaluable spiritual values (Epler, 2002; Giao et al., 2021). Tourism has been one of the important economic sectors of many countries (Hampton et al., 2018). According to the decision 2473/QĐ-TTg about "Vietnamese tourism development strategies to 2020, a vision to 2030" approved on 30/12/2011 by Deputy Prime Minister Nguyen Thien Nhan, tourism is a key economic sector with high competitiveness. The tourism industry contributed over $9.2 \%$ to the total national GDP in 2019; created 2.9 million jobs (GSO, 2020; Nhandan, 2021). Generally, in the period 2015-2019, the tourism industry achieved a high growth rate of $22.7 \%$ (Nhandan, 2021). The achievements of Vietnam's tourism sector have been highly recognized by the world; for instance, the World Tourism Organization (UNTWO) ranked Vietnam sixth in the ten countries with the highest tourism growth in the world (UNWTO, 2019). Vietnam has become an attractive destination in Southeast Asia, particularly eco-tourism sector.

The eco-tourism associated with local and cultural values can help diversifying tourism business activities, solving the outlets for local products, improving the added value for local farmers and creating jobs for local people (Epler, 2002). The eco-tourism and community-based tourism in Vietnam in general and the Mekong Delta in particular has been developing remarkably, many eco-tourism destinations with typically and locally cultural values were developed and become more attractive for domestic and foreign tourists, promoting local economic growth (Hampton et al., 2018; Giao et al., 2021). The demand for eco-tourism has been increasing as the Vietnamese economic conditions improve, the tourists are more likely to participate, learn and experience locally cultural values during their trips and to contribute to natural conservation (Hunter and Green, 1995). Eco-tourism is considered as a sustainable pathway of tourism and will be developed remarkably in the future (Brătucu et al., 2017; Tung, 2020). According to UNWTO (2019); GSO (2020), the total tourist arrivals in 2019 in Vietnam was about 103 million, of which the international arrivals accounted for 17.48\% (equivalent to 18 million) and the domestic visitors shared 82.52\%. As compared to 2010, the total international arrivals in 2019 increased 3.6 times while the domestic visitors tripled during the same period. These figures imply that the tourism development strategies for domestic market segment is important, particular under the context of Covid-19 pandemic.

In order to contribute to the rural economic development, the Vietnamese government promulgated Decision 490/QĐ-TTg on 07/08/2018 to deploy a national program namely OCOP - "One Commune One Product" movement. The OCOP movement aims at developing the rural economy based on indigenous strengths in terms of natural resources and human capital. The main focuses of the OCOP movement are to develop agricultural, non-agricultural products and services that have comparative advantages in each locality. Eco-tourism is considered as one of six groups of OCOP products that help to deliver OCOP products and other local dishes/food to visitors. Previous studies show that the Mekong Delta has favorable conditions for eco-tourism development (Nghi et al., 2012; Nhan, 2013; Tu Trinh et al., 2018; Tung, 2020). However, the eco-tourism in the Mekong Delta is still spontaneous and small; some tourism products are not really attractive to tourists; marketing and promotion strategies was not given enough attention;

\footnotetext{
* Corresponding author
} 
infrastructure and facilities at eco-tourism destinations were still poor (Nhan, 2013; Uyen, 2018; Giao et al., 2021). Although there have been some studies that consider about the tourist satisfaction on the eco-tourism in Vietnam and in the Mekong Delta were conducted, these studies ignored the potentialities for the development of OCOP eco-tourism destinations, particularly the community development, environmental protection and social connection attributes (Epler, 2002; Nhan and Canh, 2011; Hai, 2012; Nhan, 2014; Tung, 2020; Giao et al., 2021). Thus, investigating the domestic tourist satisfaction is essential for improving and developing new OCOP standardized tourism destinations and taking advantages in terms natural conditions and diversified cultural values in the Mekong Delta.

\section{LITERATURE REVIEW}

\section{Tourist satisfaction}

Tourist satisfaction (TOUSAT) plays an important role in the success of tourist destinations in particular and tourism industry in general because it affects the tourist behavior of choosing a destination, experiencing products and services, and retaining their loyalty (Parasuraman et al., 1988; Clemes et al., 2011). According to Parasuraman et al. (1988), the satisfaction is the difference between expectations and experiences. Some previous studies also proved that the interaction between the perceived values and the expectations about tourism destinations reflects the tourist satisfaction (Kozak, 2001; Hau and Omar, 2014; Oliver, 2014; Trang and Dang, 2019; Giao et al., 2021).

\section{Destination attributes}

From the literature review, various destination attributes have been recognized, including cultural attractions, natural environment, local cuisine, perceived price, safety and security, service facilities and entertainment activities (Oliver, 1980; Parasuraman et al., 1988; Baker and Crompton, 2000; Coban, 2012; Oliver, 2014). In this current study, tourist satisfaction was predicted by seven destination attributes, which are described in details as below:

The first attribute, shared social and environmental responsibilities (SOENRE) is an important attribute for green and eco-tourism development (Epler, 2002; Nuva et al., 2009; Cheung and Jim, 2014; Hultman et al., 2015; Patwary et al., 2021; Setokoe, 2021). This attribute is an important indicator for a certain eco-tourism destination to be recognized as an OCOP destination. In the field of consumption behavior, to promote ethically and eco-friendly products, consumers must be aware of and care about the environmental and social effects of their own consumption (Seyfang, 2005; Megicks et al., 2008; Mancini et al., 2017). Thus, the positive perception of tourists on shared social and environmental responsibilities may have a great effect on tourist satisfaction.

Second, destination images (DESIMA) is an important predictor of tourist satisfaction and selection decisions (Coban, 2012; Thanh Nga, 2020). Many previous studies investigated the impact of this attribute on tourists' perceived service quality and loyalty or revisit (Jensen, 2011; Ma et al., 2018; Carvache-Franco et al., 2021). In the fields of ecotourism industry, the destination images refer to the impressions or emotions of tourists has toward a destination in terms of cultural values, experiences and distinguishing characteristics or values (Tsiotsou and Vasioti, 2006; Borowiecki and Castiglione, 2014; Suki, 2014).

Third, service facilities (SERFAC) play an important role in determining the tourist satisfaction. It is a tangible attribute that mentions to transportation, local souvenirs, information centers, hygiene facilities, etc. Previous studies show that the service facilities are significantly associated with tourist satisfaction (Murphy et al., 2000; Hau and Omar, 2014).

Four, local food and safety (LOFOSA) is an important factor affect the tourist satisfaction (Pizam et al., 1978; Ryu and Jang, 2006). As the economic conditions improve, consumers are willing to pay a higher premium for locally produced foods (Onozaka and McFadden, 2011; Ferrazzi et al., 2017). Experiencing eco-tourism is considered as a reasonable way for tourists or consumers to taste fresh local dishes and specialties, particularly in OCOP tourism destinations.

Fifth, perceived price (PERPRI) refers to a consumer's willingness to pay for a certain amount of money to acquire a certain service (Bowen and Chen, 2001). It implicitly consists of two costs: monetary and non-financial costs (Bowen and Chen, 2001; Mai et al., 2019). Of which, monetary costs reflect the tourists' perceived satisfaction for what they paid (Ozturk and Qu, 2008). Previous studies show that the tourists can remember the exact prices of unreasonable payment of the past trips (Ozturk and Qu, 2008; Mai et al., 2019).

Sixth, natural environment (NATENV) is an important attribute of eco-tourism that is positively correlated with tourist satisfaction (Beerli and Martin, 2004; Coban, 2012). This attribute consists of weather, atmosphere, orchid garden, diversity of fruits, fishing ponds, etc. Previous studies show that eco-tourism will grow more as the economic conditions improve (Epler, 2002). The tourists are willing to pay more for experiencing eco-tourism activities and enjoying the natural environment of a eco-friendly destination (Nuva et al., 2009; Hultman et al., 2015).

Seventh, entertainment activities (ENTACT) is also an important attribute that affect the satisfaction of tourists about a destination. This attribute consists of outdoor activities, adventure activities, shopping, etc. (Tsiotsou and Vasioti, 2006). This attribute was employed in many previous studies to investigate the relationship with tourist satisfaction (Tsiotsou and Vasioti, 2006; Jensen, 2011; Ozdemir et al., 2012).

\section{OCOP eco-tourism destinations}

The "One Commune One Product" movement in Vietnam is a copy version of OVOP program initially developed in Oita prefecture, Japan in 1979 (Trang and Dang, 2019). In Vietnam, the OCOP movement was first piloted in Quang Ninh province since 2013 and has recorded some remarkable achievements (Hoang Thanh et al., 2018). Then, the Deputy Prime Minister Vuong Dinh Hue promulgated Decision 490/QĐ-TTg on 07/08/2018 about "approval of OCOP program for the 
period 2018-2020" to implement the OCOP program nationwide. This movement in Vietnam aims at finding and promoting competitive and marketable products with regards to local and indigenous resources to contribute to improving added value and enhancing the local economy. Like the OVOP program in Japan, the OCOP movement in Vietnam also contains three main principles: (1) Act locally, think globally, (2) Self-Reliance and Creativity and (3) Human Resource Development.

According to Decision 1048/QĐ-TTg approved by Deputy Prime Minister Vuong Dinh Hue on 21/08/2019 about the promulgation of a set of criteria for evaluating and classifying OCOP products, the OCOP movement includes six groups of products: foods; drinks and beverages; herbal; handicrafts and decorations; and community tourism and tourism destinations. Of which, tourism is one of important OCOP products that helps to conserve locally cultural values, to promote rural socio-economic development and to deliver local products efficiently and directly to consumers.

\section{Conceptual framework}

Based on the theoretical approaches of previous studies, the current study proposes the conceptual framework to investigate the impacts of eco-tourism destination attributes on tourist satisfaction. Figure 2 represents the hypothetical causal model of this current study.

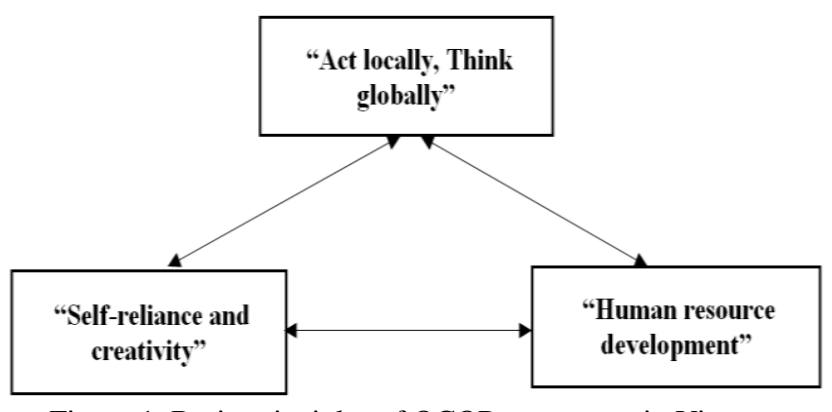

Figure 1. Basic principles of OCOP movement in Vietnam (Source: MARD, 2020)

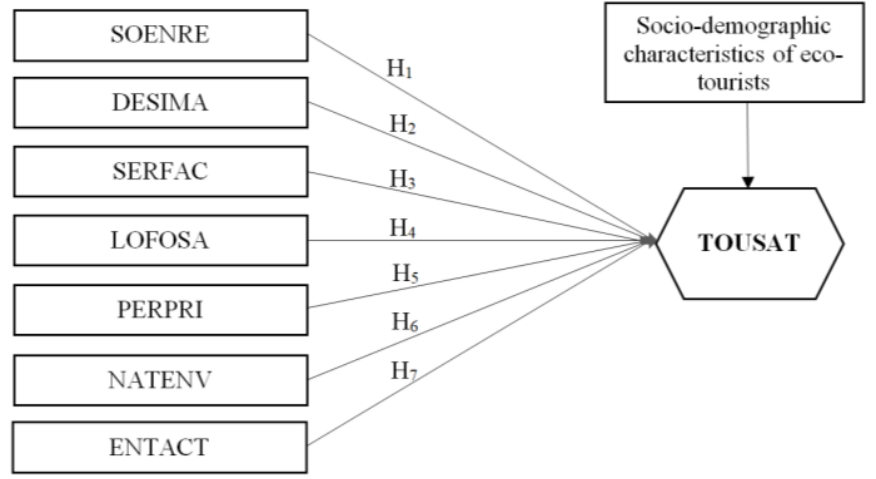

Figure 2. Conceptual framework of the current study

Note: SOENRE = shared social and environmental responsibilities; DESIMA = destination images; SERFAC = service facilities; LOFOSA = local food and safety; PERPRI = perceived price; NATENV = natural environment ENTACT = entertainment activities; TOUSAT $=$ Tourist satisfaction. The arrows indicate the relationships of independent variables with the dependent variable.

Based on Figure 2, the current study aims at testing the following seven hypotheses:

Hypothesis 1 ( $\left.\mathbf{H}_{\mathbf{1}}\right)$ : Tourists' perception on shared social and environmental responsibilities at eco-tourism destinations are positively correlated with tourist satisfaction.

Hypothesis $2\left(\mathbf{H}_{2}\right)$ : The attribute of eco-tourism destination images is positively associated with tourist satisfaction.

Hypothesis $3\left(\mathbf{H}_{3}\right)$ : The attribute of service facilities is positively associated with tourist satisfaction.

Hypothesis $4\left(\mathbf{H}_{\mathbf{4}}\right)$ : The attribute of local food and safety is positively associated with tourist satisfaction.

Hypothesis $5\left(\mathbf{H}_{5}\right)$ : The attribute of perceived price is positively associated with tourist satisfaction.

Hypothesis $\mathbf{6}\left(\mathbf{H}_{\mathbf{6}}\right)$ : The attribute of natural environment is positively associated with tourist satisfaction.

Hypothesis $7\left(\mathbf{H}_{7}\right)$ : The attribute of entertainment activities is positively associated with tourist satisfaction.

Besides these hypotheses, the current study also used control variables representing for tourists' socio-demographic characteristics in the model to investigate the impacts of destination attributes on the tourist satisfaction.

\section{METHODOLOGY}

\section{Scale measurement}

The current study employed a 5-point Likert scale ranging from "strongly disagree" to "strongly agree" to measure the tourists' perception on proposed statements. The scales and items for eco-tourism destination attributes were adapted from (Jensen, 2011; Mohamad et al., 2011; Hultman et al., 2015). Regarding the core characteristics of OCOP tourism, the study followed Decision 781/QĐ-TTg approved by Deputy Prime Minister Trinh Dinh Dung on 08/06/2020. The scales of tourist satisfaction were adapted from Mai et al. (2019); Giao et al. (2021). As mentioned in the conceptual framework, some socio-demographic variables such as age, gender, income, family size, educational level, were also evaluated to describe the tourist background and used in the regression as control variables.

\section{Data collection}

The current study was conducted in the Mekong Delta where attracted more than 47 million tourists in 2019. In 2019, the total revenue of the tourist industry was estimated about VND 30,000 billions (Nhandan, 2021). The Mekong Delta has favorable conditions for eco-tourism development (VNAT, 2020). In 2019, Can Tho city welcomed 8.8 million visitors, including both domestic and international travelers. Hau Giang attracted 486 thousand visitors in 2019, an increase of $16 \%$ as compared to that in 2018. Thus, the study selected Hau Giang province and Can Tho city as the study sites (Figure 3 for more detail). In these study sites, we conducted face-to-face interviews with domestic eco-tourists who had experienced eco-tourist destinations and services. The eco-tourism destinations where the interviews were conducted include My Khanh 
Orchard, Ong De eco-tourism, Xeo Nhum eco-tourism, Lung Ngoc Hoang eco-tourism, Tu Sang Bamboo street, Can Duc Pineapple based community tourism. The total sample size in this current study is 200 .

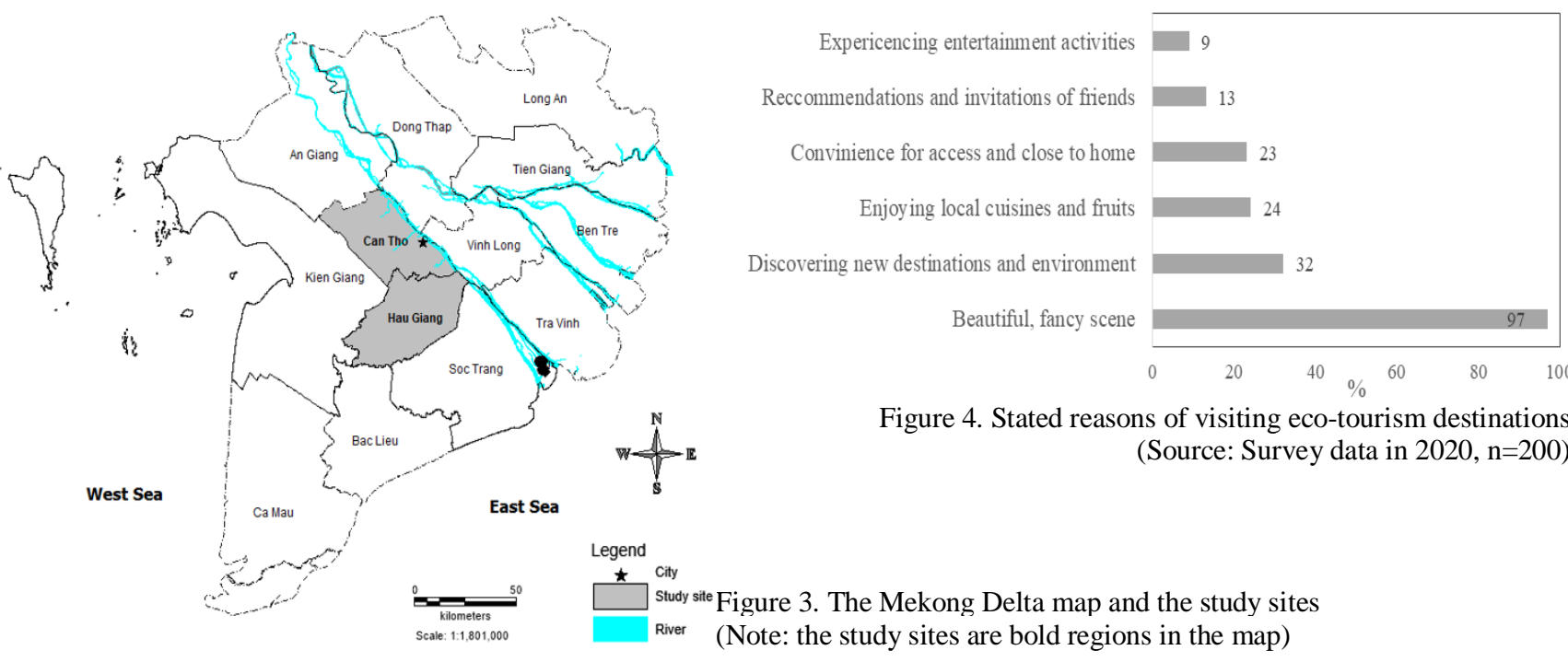

\section{Data analysis}

In order to analyze the factors affecting the domestic tourist satisfaction about eco-tourism destinations in the Mekong Delta, the study employed a combination of two analytical methods, including (1) exploratory factor analysis (EFA) and (2) multiple regression. The former was used to obtain the latent constructs representing for a set of items about the seven destination attributes. The latter was used to investigate the impact of destination attributes on tourist satisfaction. Prior to conducting EFA analysis, the constructs' reliability and validity was evaluated by testing the factor loadings and Cronbach's Alpha (Raboca, 2006; Chrysochou and Festila, 2019). The dependent variable (Y) was measured through 4 items with the 5-level Likert scale (see Table 2 for details).

Thus, the function representing the relationship between destination attributes and tourist satisfaction is presented as below.

$$
Y_{\mathrm{i}}=\beta_{0}+\sum_{\mathrm{k}=1}^{n} \beta_{\mathrm{k}} F_{\mathrm{ki}}+\beta_{2} \text { GENDER }_{\mathrm{i}}+\beta_{\mathrm{a}} \text { EDU }_{\mathrm{i}}+\beta_{4} \text { FAMSIZE }_{\mathrm{i}}+\beta_{5} I N C O M E_{\mathrm{i}}
$$

In which: $Y_{\hat{\mathbb{1}}}$ is the tourist satisfaction about eco-tourism destinations; $\beta_{i s}$ are the parameters to be estimated; $F_{k}$ are the latent constructs representing for destination attributes; $\varepsilon_{i}$ : the error term in the model; GENDER, EDU, FAMSIZE and INCOME are the socio-demographic characteristics of the eco-tourists.

\section{RESULTS AND DISCUSSIONS}

\section{Socio-demographics of eco-tourists}

Socio-demographic characteristics of the ecotourists may play an important role in shaping their decisions. Table 1 shows that the average household income of respondents was VND 18.560 millions/month and the income varies greatly among tourists. The majority of tourists had above 14 years of education. The average age of the study tourists was 37.3. Male and female respondents share a similar proportion. On the average, the family size of the study tourists was 4 , which is in line with the average family size of the Mekong Delta and Vietnam (Hoang Thanh et al., 2018; Tu et al., 2021).

The study also investigated the drivers behind the tourists' choices of vising eco-tourism destinations, which are illustrated in Figure 4. The study shows that the majority of eco-tourists (97\%) are attracted by the beautiful and fancy scenes. Besides, discovering new destinations and environment is also an important factor affecting the travelling decisions of eco-tourists, this segment shares $32 \%$ of total study respondents. Enjoying local cuisines and fruits also play an important role in shaping the tourists' selection decisions.

\section{Measurement of scales}

Table 2 provides a summary of the responses to the survey items that measured perceptions of domestic tourists about the destination attributes. Generally, the survey respondents held favorable perceptions about the destination attributes of eco-tourism in the study sites. Specifically, all survey items reported average scores above 4. Of which, the destination images are top rated by eco-tourists.

Table 1. Socio-demographic characteristics of eco-tourist (Source: Survey data in 2020, $\mathrm{n}=200$ )

\begin{tabular}{|c|c|c|c|c|c|}
\hline Variables & Unit & Mean & S.D & Min & Max \\
\hline Income & VND 1000/month & 18,560 & 5,577 & 7,500 & 25,000 \\
\hline Education & & & & & \\
\hline Primary school & & 0.04 & 0.19 & 0 & 1 \\
\hline Secondary school & & 0.16 & 0.37 & 0 & 1 \\
\hline High school & & 0.27 & 0.45 & 0 & 1 \\
\hline Professional qualification & & 0.09 & 0.29 & 0 & 1 \\
\hline University degree & & 0.43 & 0.50 & 0 & 1 \\
\hline Higher education & & 0.01 & 0.10 & 0 & 1 \\
\hline Age & Years & 37.30 & 10.89 & 19 & 71 \\
\hline Gender & Dummy (1 male) & 0.53 & 0.50 & 0 & 1 \\
\hline Household size & Persons & 3.54 & 1.16 & 2 & 7 \\
\hline
\end{tabular}


Table 2. Tourists' perceptions about the destination attributes (Source: Survey data in 2020, $n=200$ )

\begin{tabular}{|c|c|c|c|}
\hline Items & Notation & Mean & SD \\
\hline \multicolumn{4}{|l|}{ SOENRE: Shared social and environmental responsibilities } \\
\hline Eco-tourism destinations in a province are well connected & SO1 & 4.40 & 0.49 \\
\hline Eco-tourism contributes to local community development & $\mathrm{SO} 2$ & 4.71 & 0.45 \\
\hline Environmental protection is shared by community & $\mathrm{SO} 3$ & 4.73 & 0.44 \\
\hline Local labors are employed for tourism activities & SO4 & 4.72 & 0.45 \\
\hline \multicolumn{4}{|l|}{ DESIMA: Destination images } \\
\hline There are many beautiful places for check-in & DE1 & 4.79 & 0.40 \\
\hline There are many outdoor activities & DE2 & 4.80 & 0.39 \\
\hline Easy to access and well-connected with other destinations & DE3 & 4.79 & 0.40 \\
\hline Wide ranges of fruits/birds/fish species/animal & DE4 & 4.84 & 0.36 \\
\hline \multicolumn{4}{|l|}{ SERFAC: Service facilities } \\
\hline Availability of free wifi access & SE1 & 4.56 & 0.55 \\
\hline Availability of local souvenirs & SE2 & 4.80 & 0.41 \\
\hline Availability of travel information & SE3 & 4.87 & 0.35 \\
\hline Convenience for commuting inside the destinations & SE4 & 4.88 & 0.34 \\
\hline \multicolumn{4}{|l|}{ LOFOSA: Local food and safety } \\
\hline Diverse availability of local cuisines/foods/fruits & LO1 & 4.84 & 0.36 \\
\hline Quality of cuisines/foods/fruits & $\mathrm{LO} 2$ & 4.78 & 0.41 \\
\hline Food services at the destinations are clean and safe & LO3 & 4.74 & 0.43 \\
\hline \multicolumn{4}{|l|}{ PERPRI: Perceived price } \\
\hline Reasonable price of cuisines & PE1 & 4.86 & 0.37 \\
\hline Reasonable price of entertainment activities & PE2 & 4.85 & 0.38 \\
\hline This is the price that I would expect to pay & PE3 & 4.83 & 0.41 \\
\hline \multicolumn{4}{|l|}{ NATENV: Natural environment } \\
\hline Fresh air, cool environment & NA1 & 4.83 & 0.36 \\
\hline Wide and clean space & NA2 & 4.75 & 0.49 \\
\hline Variety of beautiful and natural landscapes & NA3 & 4.83 & 0.41 \\
\hline Friendly local people & NA4 & 4.84 & 0.42 \\
\hline \multicolumn{4}{|l|}{ ENTACT: Entertainment activities } \\
\hline Variety of entertainment activities/events & EN1 & 4.62 & 0.52 \\
\hline Variety of locally cultural activities such as traditional music & EN2 & 4.73 & 0.47 \\
\hline Variety of experience activities such as fishing, pick-up fruits, etc. & EN3 & 4.64 & 0.52 \\
\hline \multicolumn{4}{|l|}{ TOUSAT: Tourist satisfaction } \\
\hline Satisfied with the overall services and quality & SAT1 & 4.59 & 0.49 \\
\hline Satisfied with the natural environment & SAT2 & 4.55 & 0.50 \\
\hline Satisfied with the local foods and entertainment activities & SAT3 & 4.45 & 0.49 \\
\hline Satisfied with the way that the social and environmental responsibilities are shared & SAT4 & 4.49 & 0.50 \\
\hline
\end{tabular}

Table 3. Measurement of scale reliability using Cronbach's Alpha (Source: Survey data in 2020, $n=200$ )

\begin{tabular}{|c|c|c|c|c|}
\hline No & Factors & Number of items included & Number of items excluded & Cronbach's Alpha \\
\hline 1 & TOUSAT & 4 & 0 & 0.814 \\
\hline 2 & SOENRE & 3 & 1 & 0.934 \\
\hline 3 & DESIMA & 4 & 0 & 0.920 \\
\hline 4 & SERFAC & 3 & 1 & 0.915 \\
\hline 5 & LOFOSA & 3 & 0 & 0.816 \\
\hline 6 & PERPRI & 3 & 0 & 0.894 \\
\hline 7 & NATENV & 4 & 0 & 0.800 \\
\hline 8 & ENTACT & 3 & 0 & 0.841 \\
\hline
\end{tabular}

Note: The items with total correlation below 0.5 were removed. Note: SOENRE $=$ shared social and environmental responsibilities; DESIMA $=$ destination images; SERFAC $=$ service facilities; LOFOSA = local food and safety; PERPRI $=$ perceived price; NATENV = natural environment; ENTACT $=$ entertainment activities; TOUSAT $=$ Tourist satisfaction

In general, Table 2 also shows that the eco-tourists are highly satisfied with the services, quality, environment and core characteristics of OCOP eco-tourism (shared social and environmental responsibilities). In this current study, the items with total correlation under 0.5 were removed from the analysis. Thus, the items SO1 and SE1 were excluded from the EFA. The results of the scale reliability test (Table 3) show that the Cronbach's Alpha coefficients of the scales are all higher than 0.8. George and Mallery (2003) suggested the rules of thumb: the coefficient of Cronbach's Alpha above 0.8 and 0.9 indicated excellent and good internal consistency of the items, respectively. Thus, all scales concerned in this study were acceptable for EFA. The EFA results in Table 4 show that the value of KMO test $=0.74$ (greater than 0.5) and Bartlett's test of sphericity $\chi^{2}=3206$ indicate that the survey items may explain the variance of the underlying factors and may be used for structure detection at the significance level of $1 \%$. The EFA results also show that there are 7 components with the eigenvalues greater than 1 . The total variance explained by the seven components was $80.41 \%$, indicating that the latent constructs could explain $80.41 \%$ of variation. After excluding the two items SO1 and SE1, the current study used 23 items for the EFA with Principal Component method and using Varimax rotation. The result shows that all items have factor loadings greater than 0.6. According to Hair et al. (2011), the factor loadings above 0.6 indicated that the individual items 
are acceptable for explaining the latent constructs. Table 4 also shows that the composite reliabilities ranged from $0.84-$ 0.94, indicating that the latent components were acceptable. Hair et al. (2011) suggested that the threshold for average variance extracted was 0.5 . In this current study, all the values of the average variance extracted were above the threshold. These results suggest that the latent constructs were all confirmed in terms of reliability and validity.

Table 4. Rotated factor loadings and measurement evaluation (Source: Survey data in 2020, $\mathrm{n}=200$ )

\begin{tabular}{|c|c|c|c|c|c|c|c|c|}
\hline \multirow{2}{*}{ No. } & \multirow{2}{*}{ Items } & \multicolumn{7}{|c|}{ Component } \\
\hline & & 1 & 2 & 3 & 4 & 5 & 6 & 7 \\
\hline DE4 & Wide ranges of fruits/birds/fish species/animal & 0.94 & & & & & & \\
\hline DE2 & There are many outdoor activities & 0.89 & & & & & & \\
\hline DE3 & Easy to access and well-connected with other destinations & 0.89 & & & & & & \\
\hline DE1 & There are many beautiful places for check-in & 0.85 & & & & & & \\
\hline SE4 & Convenience for commuting inside the destinations & & 0.95 & & & & & \\
\hline SE3 & Availability of travel information & & 0.92 & & & & & \\
\hline SE2 & Availability of local souvenirs & & 0.84 & & & & & \\
\hline SO4 & Local labors are employed for tourism activities & & & 0.95 & & & & \\
\hline $\mathrm{SO} 2$ & Eco-tourism contributes to local community development & & & 0.94 & & & & \\
\hline SO3 & Environmental protection is shared by community & & & 0.91 & & & & \\
\hline NA3 & Variety of beautiful and natural landscapes & & & & 0.81 & & & \\
\hline NA1 & Fresh air, cool environment & & & & 0.79 & & & \\
\hline NA4 & Friendly local people & & & & 0.78 & & & \\
\hline NA2 & Wide and clean space & & & & 0.62 & & & \\
\hline PE1 & Reasonable price of cuisines & & & & & 0.91 & & \\
\hline PE3 & This is the price that I would expect to pay & & & & & 0.88 & & \\
\hline PE2 & Reasonable price of entertainment activities & & & & & 0.86 & & \\
\hline EN1 & Variety of entertainment activities/events & & & & & & 0.91 & \\
\hline EN3 & Variety of experience activities (fishing, pick-up fruits) & & & & & & 0.86 & \\
\hline EN2 & Variety of locally cultural activities (traditional music) & & & & & & 0.81 & \\
\hline LO1 & Diverse availability of local cuisines/foods/fruits & & & & & & & 0.89 \\
\hline LO2 & Quality of cuisines/foods/fruits & & & & & & & 0.87 \\
\hline LO3 & Food services at the destinations are clean and safe & & & & & & & 0.80 \\
\hline \multicolumn{2}{|r|}{ Average variance extracted (AVE) } & 0.80 & 0.82 & 0.87 & 0.57 & 0.78 & 0.74 & 0.73 \\
\hline Com & osite reliability $(\mathrm{CR})$ & 0.94 & 0.93 & 0.95 & 0.84 & 0.91 & 0.90 & 0.89 \\
\hline \multicolumn{5}{|c|}{$0.5<\mathrm{KMO}=0.74<1 ;$ Bartletts test: Sig. $=0.000<0.05$} & & & & \\
\hline \multicolumn{5}{|c|}{ Total variance explained: 80.41} & & & & \\
\hline
\end{tabular}

\section{Determinants of domestic tourist satisfaction}

Now, we turn to investigate the factors affecting the domestic tourist satisfaction. The correlation coefficients of each couple of dependent variables are below 0.5 , indicating that there is no multicollinearity in the model. In this current study, we estimated two models: model 1 without socio-demographic characteristics and model 2 with sociodemographic characteristics. The multiple regression results are presented in Table 5.

Table 5 shows that the $\mathrm{R}^{2}$ in model 1 is 33.72 , indicating that the destination attributes could explain only $33.72 \%$ of the variation of domestic eco-tourist satisfaction. The model 2 could explain more than $57 \%$ of variation of

tourist satisfaction. These results indicate that the model 2 is better fit with the observed data. Thus, this current study used the estimated results from model 2 to test the proposed hypotheses. Table 5 shows that there are three control variables (sociodemographic characteristics) namely gender, educational level and family size of the eco-tourists that have positive relationship with the tourist satisfaction. These finding are consistent with the previous studies of Hansen (2005). Gender of the tourist has the greatest coefficient in the model, which indicate that male eco-tourists have a higher level of satisfaction as compared to female eco-tourists. This result is not consistent with the previous finding of Giao et al. (2021). However, other previous studies showed that male tourists hold a higher level of satisfaction (Suki, 2014; Wu et al., 2014). This result suggests that eco-tourism providers should place great emphasis on improving the satisfaction of female tourists through upgrading service quality, service delivery and reliability. Another finding is that the eco-tourists with higher educational level and more family members have a higher satisfaction level. This result is not consistent with the findings of Jensen (2011); CarvacheFranco et al. (2021) that the eco-tourists with lower educational levels feel more satisfied with their visits. However, the finding from this current study is consistent with the studies of Tsiotsou and Vasioti (2006); Ozdemir et al. (2012); Ma et al. (2018). 
Regarding to the destination attributes, Table 5 shows that there are five destination attributes (SOENRE, DESIMA, SERFAC, NATENV and ENTACT) that are positively and significantly correlated with the domestic tourist satisfaction. The remaining two attributes namely local food and safety and perceived price are not significantly associated with the tourist satisfaction. With these results, we can confirm that the hypotheses $\mathrm{H}_{4}$ and $\mathrm{H}_{5}$ are not supported.

Table 5 also shows that the most important attribute namely shared social and environmental responsibilities has the highest coefficient of 0.227 . This result suggests that the eco-tourism destinations that have social and environmental responsibilities shared properly and equally among communities will help to increase the satisfaction level of eco-tourists. As mentioned, shared social and environmental responsibilities are really important for sustainable eco-tourism development (Cheung and Jim, 2014; Hultman et al., 2015; Setokoe, 2021). From these results, we suggest that it is necessary for the ecotourism providers to establish and operate the properly shared systems of environmental and social responsibilities.

SERFAC or service facilities at the eco-tourism destinations has a positive and significant relationship with the tourist satisfaction. This attribute has the second largest estimated coefficient, suggesting that it has a great impact on tourist satisfaction. This result was confirmed in the previous findings (Chi and Qu, 2008; Mai et al., 2019; Trang and Dang, 2019; Giao et al., 2021). For policy implications, this result suggests that the eco-tourism providers should pay more attention on upgrading their service facilities. ENTACT or entertainment activities has the estimated coefficient of 0.184 , indicating that this attribute is also an important predictor of domestic eco-tourist satisfaction. This result is in line with the previous studies (Trang and Dang, 2019; Giao et al., 2021). Giao et al. (2021) indicated that entertainment activities have the greatest impact on tourist satisfaction. Thus, the study suggests that diversifying entertainment activities such as fishing, practice of local food making, pick-up fruits, etc. are required to improve the domestic eco-tourist satisfaction.

Table 5 also indicates that DESIMA or destination images is positively and significantly correlated with the domestic tourist satisfaction. Many previous studies argued that destination images play an important role in determining the satisfaction level (Jensen, 2011; Kwok et al., 2016; Ma et al., 2018). In reality, many tourists outside the Mekong Delta such as the north and central of Vietnam would like to experience the eco-tourism activities, however many visitors perceived that the majority of destinations in the Mekong Delta shared a certain level of similarities. In addition, marketing strategies for eco-tourism were not paid enough attention. Thus, building the uniquely attractive images, particular at OCOP eco-tourism destinations is necessary.

Experiencing and enjoying natural environment is also an important predictor of tourist satisfaction. This result is consistent with many previous findings (Murphy et al., 2000; Tsiotsou and Vasioti, 2006; Coban, 2012). Economic theory would suggest that economic development that improves individual consumers' wellbeing initially leads to deterioration of the environment, but after a certain level of economic growth a society begins to improve its relationship with the environment and can reduce levels of environmental degradation (Arrow et al., 1995; Cole et al., 1997). Thus, the tourism sector, tourism providers and managers should pay high attention in protecting the natural environment. From the estimated results, the current study proposes some solutions for sustainable development of ecotourism sectors in general and OCOP standardized eco-tourism destinations in particular.

(1) Focusing on the target market of urban tourists who would like to experience local community life such as fishing, practice of local food making, pick-up fruits, harvesting vegetables, cycling, camping, sailing boats.

(2) Diversifying special tourism products and entertainment activities associated with local products, indigenous strengths to promote local products, contributing to the successful implementation of the OCOP movement.

(3) Encouraging the participation of the local community in promoting tourism images such as preserving and protecting environment, a civilized and polite lifestyle, creating sympathy for visitors under the motto "sharing responsibilities and enhancing the benefits for local communities".

(4) Building the uniquely attractive images, particular at OCOP eco-tourism destinations and the advertising and marketing strategies should be paid more attention as the majority of domestic tourists are young and search for travelling information through internet.

(5) Training and improving the competency of staff members, tourism servers and tour guide is important to improve the service quality, which in turns contribute to the improvement of tourist satisfaction.

As other previous studies, this current study also has some limitations. First, this study doesn't capture the moderating roles of gender, educational level in investigating the factors affecting tourist satisfaction while these socio-demographic characteristics are important moderating variables (Jensen, 2011; Suki, 2014). Further studies are required to consider the differences in perceptions about the eco-tourist destination attributes or the moderating roles of socio-demographic characteristics. Second, the destination attributes and the socio-demographic characteristics included in the model could explain only $57 \%$ of the variation of tourist satisfaction. Thus, it is recommended that the further research should consider more destination attributes and socio-demographic characteristics in the conceptual framework.

\section{CONCLUSIONS}

The current study employed the exploratory factor analysis and multiple regression to investigate the impacts of destination attributes, including the core characteristics of OCOP tourism products and socio-demographic characteristics of domestic eco-tourists on domestic tourist satisfaction. The study found that the shared social and environmental responsibilities - core characteristics of OCOP tourism products have the highest effect on tourist satisfaction. This result is an important empirical evidence for local authorities to encourage tourism providers to join OCOP movement and to focus on the establishment of a good mechanism of shared social and environmental responsibilities. In addition, the study also provides a strong evidence regarding to the positive impacts of destination 
images, service facilities, natural environment and entertainment activities on tourist satisfaction. This study also provides some practical implications for sustainable development of eco-tourism sector in the Mekong Delta.

Funding: This study was partly funded by Hau Giang Department of Science and Technology.

Conflicts of Interest: The authors declare no conflicts of interest.

\section{REFERENCES}

Arrow, K., Bolin, B., Costanza, R., Dasgupta, P., Folke, C., Holling, C.S., Jansson, B.O., Levin, S., Mäler, K.G., \& Perrings, C. (1995). Economic growth, carrying capacity, and the environment. Ecological economics, 15(2), 91-95. https://doi.org/10.1016/0921-8009(95)00059-3

Baker, D.A., \& Crompton, J.L. (2000). Quality, satisfaction and behavioral intentions. Annals of Tourism Research, 27(3), 785-804. https://doi.org/10.1016/S0160-7383(99)00108-5

Beerli, A., \& Martin, J.D. (2004). Factors influencing destination image. Annals of tourism research, 31(3), 657-681. https://doi.org/10.1016/j.annals.2004.01.010

Borowiecki, K.J., \& Castiglione, C. (2014). Cultural participation and tourism flows: an empirical investigation of Italian provinces. Tourism Economics, 20(2), 241-262. https://doi.org/10.5367/te.2013.0278

Bowen, J.T., \& Chen, S.L. (2001). The relationship between customer loyalty and customer satisfaction. International journal of contemporary hospitality management. https://doi.org/10.1108/09596110110395893

Brătucu, G., Băltescu, C.A., Neacșu, N.A., Boșcor, D., Țierean, O.M., \& Madar, A. (2017). Approaching the sustainable development practices in mountain tourism in the Romanian Carpathians. Sustainability, 9(11), 2051. https://doi.org/10.3390/su9112051

Carvache-Franco, M., Carvache-Franco, O., Víquez-Paniagua, A.G., Carvache-Franco, W., \& Perez-Orozco, A. (2021). Sociodemographic aspects and their relationship with motivations, satisfaction and loyalty in ecotourism: a study in Costa Rica. Journal of Cultural Heritage Management and Sustainable Development. https://doi.org/10.1108/JCHMSD-12-2020-0184

Cheung, L.T., \& Jim, C.Y. (2014). Expectations and willingness-to-pay for ecotourism services in Hong Kong's conservation areas. International Journal of Sustainable Development \& World Ecology, 21(2), 149-159. https://doi.org/10.1080/13504509.2013.859183

Chi, C.G.Q., \& Qu, H. (2008). Examining the structural relationships of destination image, tourist satisfaction and destination loyalty: An integrated approach. Tourism management, 29(4), 624-636. https://doi.org/10.1016/j.tourman.2007.06.007

Chrysochou, P., \& Festila, A. (2019). A content analysis of organic product package designs. Journal of Consumer Marketing. https://doi.org/10.1108/JCM-06-2018-2720

Clemes, M.D., Gan, C., \& Ren, M. (2011). Synthesizing the effects of service quality, value, and customer satisfaction on behavioral intentions in the motel industry: An empirical analysis. Journal of Hospitality \& Tourism Research, 35(4), 530-568. https://doi.org/10.1177/1096348010382239

Coban, S. (2012). The effects of the image of destination on tourist satisfaction and loyalty: The case of Cappadocia. European Journal of Social Sciences, 29(2), 222-232.

Cole, M.A., Rayner, A.J., \& Bates, J.M. (1997). The environmental Kuznets curve: an empirical analysis. Environment and development economics, 2(4), 401-416. https://doi.org/10.1017/S1355770X97000211

Epler, M. (2002). Ecotourism: Principles, practices \& policies for sustainability. United Nations Publication.[En línea], USA.

Ferrazzi, G., Ventura, V., Ratti, S., \& Balzaretti, C. (2017). Consumers' preferences for a local food product: the case of a new Carnaroli rice product in Lombardy. Italian journal of food safety, 6(2). https://doi.org/10.4081/ijfs.2017.6186

George, D., \& Mallery. (2003). SPSS for Windows step by step: a simple guide and reference. Boston, MA: Allyn and Bacon.

Giao, H.N.K., Vuong, B.N., Phuong, N.N.D., \& Dat, N.T. (2021). A model of factors affecting domestic tourist satisfaction on eco-tourism service quality in the Mekong Delta, Vietnam. GeoJournal of Tourism and Geosites, 36, 663-671. https://doi.org/10.30892/gtg.362spl14-696

Hai, L.T.D. (2012). Giải pháp nâng cao chất lượng dịch vụ du lịch trên địa bàn thành phố cần thơ [Solutions to improve the service quality of tourism in Can Tho city]. Scientific Journal of Can Tho University, 22b, 231-241.

Hair, J.F., Ringle, C.M., \& Sarstedt, M. (2011). PLS-SEM: Indeed a silver bullet. Journal of Marketing theory and Practice, 19(2), $139-152$.

Hampton, M.P., Jeyacheya, J., \& Long, P.H. (2018). Can tourism promote inclusive growth? Supply chains, ownership and employment in Ha Long Bay, Vietnam. The Journal of Development Studies, 54(2), 359-376. https://doi.org/10.1080/00220388.2017.1296572

Hansen, T. (2005). Understanding consumer perception of food quality: the cases of shrimps and cheese. British Food Journal. https://doi.org/10.1108/00070700510606909

Hau, T.C., \& Omar, K. (2014). The impact of service quality on tourist satisfaction: the case study of Rantau Abang Beach as a turtle sanctuary destination. Mediterranean Journal of Social Sciences, 5(23), 1827-1827.

Hoang Thanh, L., Ta Nhat, L., Nguyen Dang, H., Ho, T.M.H., \& Lebailly, P. (2018). One Village One Product (OVOP)—A rural development strategy and the early adaption in Vietnam, the case of Quang Ninh Province. Sustainability, 10(12), 4485. https://doi.org/10.3390/su10124485

Hultman, M., Kazeminia, A., \& Ghasemi, V. (2015). Intention to visit and willingness to pay premium for ecotourism: The impact of attitude, materialism, and motivation. Journal of Business Research, 68(9), 1854-1861. https://doi.org/10.1016/j.jbusres.2015.01.013

Hunter, C., \& Green, H. (1995). Tourism and the environment: A sustainable relationship?, Routledge, London, UK.

Jensen, J.M. (2011). The relationships between socio-demographic variables, travel motivations and subsequent choice of vacation. Paper presented at the 2nd International Conference on Economics, Business and Management.

Kozak, M. (2001). Comparative assessment of tourist satisfaction with destinations across two nationalities. Tourism management, 22(4), 391-401. https://doi.org/10.1016/S0261-5177(00)00064-9

Kwok, S.Y., Jusoh, A., \& Khalifah, Z. (2016). The influence of service quality on satisfaction: Does gender really matter? Intangible capital, 12(2), 444-461. http://dx.doi.org/10.3926/ic.673

Ma, A.T., Chow, A.S., Cheung, L.T., Lee, K.M., \& Liu, S. (2018). Impacts of tourists' sociodemographic characteristics on the travel motivation and satisfaction: the case of protected areas in South China. Sustainability, 10(10), 3388. https://doi.org/10.3390/su10103388

Mai, K.N., Nguyen, P.N.D., \& Nguyen, P.T.M. (2019). International tourists' loyalty to Ho Chi Minh City destination-a mediation analysis of perceived service quality and perceived value. Sustainability, 11(19), 5447. https://doi.org/10.3390/su11195447

Mancini, P., Marchini, A., \& Simeone, M. (2017). Which are the sustainable attributes affecting the real consumption behaviour? Consumer understanding and choices. British Food Journal. https://doi.org/10.1108/BFJ-11-2016-0574 
Megicks, P., Memery, J., \& Williams, J. (2008). Influences on ethical and socially responsible shopping: evidence from the UK grocery sector. Journal of Marketing Management, 24(5-6), 637-659. https://doi.org/10.1362/026725708X326039

Mohamad, M., Ali, A.M., \& Ab Ghani, N.I. (2011). A structural model of destination image, tourists'satisfaction and destination loyalty. International Journal of Business and Management Studies, 3(2), 167-177. https://dergipark.org.tr/en/pub/ijbms/issue/26069/274733

Murphy, P., Pritchard, M.P., \& Smith, B. (2000). The destination product and its impact on traveller perceptions. Tourism management, 21(1), 43-52. https://doi.org/10.1016/S0261-5177(99)00080-1

Nghi, N.Q., Bao Chau, N.T., \& Lanh, T.N. (2012). Các nhân tố ảnh hưởng đến quyết định tham gia tổ chức du lịch cộng đồng của người dân ở tỉnh An Giang [Factors affect decission to participate in community based tourism organizations of community in An Giang Province]. Scientific Journal of Can Tho University, 23b, 194-202.

Nhan, N.T. (2013). Đánh giá của du khách về du lịch sinh thái ở khu du lịch Gáo Giồng, huyện Cao Lãnh, tỉnh Đồng Tháp [Tourists' opinions of ecotourism at Gao Giong tourist site, Cao Lanh District, Dong Thap Province]. Scientific Journal of Can Tho University, 26, 22-29.

Nhan, N.T. (2014). Những nhân tố ảnh hưởng đến sự phát triển du lịch biển tỉnh Kiên Giang [Factors influencing the development of sea tourism in Kien Giang province]. Scientific Journal of Can Tho University, 30, 22-29.

Nhan, N.T., \& Canh, D.N. (2011). Thực trạng và giải pháp phát triển du lịch chợ nổi Cái Răng - thành phố Cần Thơ [Current status and solutions for tourism activity development at Cai Rang floating market in Can Tho city]. Scientific Journal of Can Tho University, 19a, 60-71.

Nhandan. (2021). Du lịch Việt Nam 2020: phát huy nội lực trong "bão Covid-19” [Vietnam tourism 2020: promoting internal strength in the "Covid-19 pandemic"].

Nuva, R., Shamsudin, M.N., Radam, A., \& Shuib, A. (2009). Willingness to pay towards the conservation of ecotourism resources at Gunung Gede Pangrango National Park, West Java, Indonesia. Journal of Sustainable Development, 2(2), 173-186.

Oliver, R.L. (1980). A cognitive model of the antecedents and consequences of satisfaction decisions. Journal of Marketing Research, 17(4), 460-469. https://doi.org/10.1177/002224378001700405

Oliver, R.L. (2014). Satisfaction: A behavioral perspective on the consumer: A behavioral perspective on the consumer: Routledge, London, UK.

Onozaka, Y., \& McFadden, D.T. (2011). Does local labeling complement or compete with other sustainable labels? A conjoint analysis of direct and joint values for fresh produce claim. American Journal of Agricultural Economics, 93(3), 693-706. https://doi.org/10.1093/ajae/aar005

Ozdemir, B., Aksu, A., Ehtiyar, R., Çizel, B., Çizel, R.B., \& İçigen, E.T. (2012). Relationships among tourist profile, satisfaction and destination loyalty: Examining empirical evidences in Antalya region of Turkey. Journal of Hospitality Marketing \& Management, 21(5), 506-540. https://doi.org/10.1080/19368623.2012.626749

Ozturk, A.B., \& Qu, H. (2008). The impact of destination images on tourists' perceived value, expectations, and loyalty. Journal of Quality Assurance in Hospitality \& Tourism, 9(4), 275-297. https://doi.org/10.1080/15280080802520552

Parasuraman, A., Zeithaml, V.A., \& Berry, L. (1988). SERVQUAL: A multiple-item scale for measuring consumer perceptions of service quality. 1988, 64(1), 12-40.

Patwary, A.K., Omar, H., \& Tahir, S. (2021). The impact of perceived environmental responsibility on tourists' intention to visit green hotel: the mediating role of attitude. GeoJournal of Tourism and Geosites, 34(1), 9-13. https://doi.org/10.30892/gtg.34101-612

Pizam, A., Neumann, Y., \& Reichel, A. (1978). Dimentions of tourist satisfaction with a destination area. Annals of tourism Research, 5(3), 314-322. https://doi.org/10.1016/0160-7383(78)90115-9

Raboca, H.M. (2006). Determinants of customer satisfaction and service quality-the case of Romanian public services. Transylvanian Review of Administrative Sciences, 2(16), 124-135.

Ryu, K., \& Jang, S. (2006). Intention to experience local cuisine in a travel destination: The modified theory of reasoned action. Journal of Hospitality \& Tourism Research, 30(4), 507-516. https://doi.org/10.1177/1096348006287163

Setokoe, T.J. (2021). Community-based tourism: a panacea for community development in Nqileni village, Eastern Cape, South Africa. GeoJournal of Tourism \& Geosites, 34(1). https://doi.org/10.30892/gtg.34104-615

Seyfang, G. (2005). Shopping for sustainability: can sustainable consumption promote ecological citizenship? Environmental politics, 14(2), 290-306. https://doi.org/10.1080/09644010500055209

Suki, N.M. (2014). Moderating role of gender in the relationship between hotel service quality dimensions and tourist satisfaction. Journal of Quality Assurance in Hospitality \& Tourism, 15(1), 44-62. https://doi.org/10.1080/1528008X.2014.855104

Thanh Nga, N.T. (2020). Phân tích các nhân tố ảnh hưởng đến sự hài lòng của khách du lịch nội địa khi đến Kiên Giang [Analyzing factors affecting the satisfaction of domestic tourists visiting Kien Giang province]. Industry and Trade Magazine, 29.

Trang, H.N.T., \& Dang, N.H. (2019). Factors affecting the tourists' satisfaction at traditional trade village tourist place in Bay Nui, An Giang province. AGU International Journal of Sciences, 7(2), 30-41.

Tsiotsou, R., \& Vasioti, E. (2006). Using demographics and leisure activities to predict satisfaction with tourism services in Greece. Journal of Hospitality \& Leisure Marketing, 14(2), 69-82. https://doi.org/10.1300/J150v14n02_05

Tu Trinh, N.T., Dao, N.H., \& Huyen, K.N. (2018). Nghiên cứu nhu cầu du lịch trải nghiệm của người dân thành phố Cần Thơ [Investigation of residents' demand on experiential tourism in Can Tho city]. Scientific Journal of Can Tho University, 54(7C), 109-116.

Tu, V.H., Kopp, S.W., Trang, N.T., Kontoleon, A., \& Yabe, M. (2021). UK Consumers' Preferences for Ethical Attributes of Floating Rice: Implications for Environmentally Friendly Agriculture in Vietnam. Sustainability, 13(15). https://doi.org/10.3390/su13158354

Tung, L. (2020). Tourism development in Vietnam: new strategy for a sustainable pathway. GeoJournal of Tourism and Geosites, 31(3), 1174-1179. https://doi.org/10.30892/gtg.31332--555

Uyen, C.P. (2018). Phát triển du lịch nông nghiệp ở Đồng bằng sông Cửu Long [Developing agri-tourism in the Mekong Delta]. Tay Do University Journal of Scientific Research and Economic Development, 04(2018).

Wu, M.Y., Wall, G., \& Pearce, P.L. (2014). Shopping experiences: international tourists in Beijing's silk market. Tourism Management, 41, 96-106. https://doi.org/10.1016/j.tourman.2013.09.010

***MARD. (2020). Tài liệu tập huấn nhũng kiến thức co bản về chuoong trình mỗi xã một sản phẩm (OCOP) dành cho chủ thể tu vấn chuong trinh OCOP [Training document on basic knowledge about the one-commune-one-product (OCOP) program for OCOP program consultants]. Ministry of Agricultural and Rural Development, Ha Noi, Vietnam.

***GSO. (2020). Statistical yearbook of Vietnam 2019. Statistical Publishing House, Ha Noi, Vietnam.

*** UNWTO. (2019). International Tourism Highlights. United Nations World Travel Organization.

*** VNAT. (2020). Connecting tourism in the Mekong Delta in response to "Vietnamese people travel to Vietnam". Retrieved 25/07/2021. https://vietnamtourism.gov.vn/index.php/items/33163 